\title{
Effects of Ochratoxin A on heavy pig production
}

\author{
Luca MALAGUTTI*, Michele ZANNOTTI, Andrea SCAMPINI, \\ Franca SCIARAFFIA
}

Istituto di Zootecnia Generale, Facoltà di Agraria, Università degli Studi di Milano, Italy

(Received 19 July 2004; accepted 31 March 2005)

\begin{abstract}
Ochratoxin A (OTA) is a widespread mycotoxin mainly produced by Aspergillus ochraceus and Penicillium verrucosum which can affect cereals and which occurs in meat and meat products. It has been demonstrated that OTA is nephrotoxic, hepatotoxic and carcinogenic in all mammalian species; pigs and poultry are the species most exposed to OTA toxicity. The aim of this research was to evaluate the effects of OTA added to the growing pigs' diet, with regards to growing parameters and the amount of OTA present in animal meat. Sixty-four pigs, divided into 2 homogenous groups, were reared for 119 days, from live weight of $41 \mathrm{~kg}$ to slaughtering. The control group was fed a commercial pig feed and the treated group was given the same feed with the addition of $25 \mu \mathrm{g} \cdot \mathrm{kg}^{-1}$ of OTA. No significant differences were observed regarding growing parameters after 62 days but at the end of the trial, OTA supplementation decreased final live body weight $(163.4 \mathrm{~kg}$ vs. $170.9 \mathrm{~kg}, P<0.05)$, average daily gain $(1030 \mathrm{~g}$ vs. $1094 \mathrm{~g}, P<0.01)$ and feed efficiency (about $-7 \%, P<0.05$ ) whilst feed intake did not differ. A higher amount of OTA was observed in the kidneys. There was also a much higher amount of OTA in the liver and semimembranosus muscle than the maximum limit of $1 \mu \mathrm{g} \cdot \mathrm{kg}^{-1}$ established by the European Union for human consumption food.
\end{abstract}

ochratoxin A / pigs / growth parameters / meat

Résumé - Effets de l'Ochratoxine A sur la production du porc lourd. L'Ochratoxine A (OTA) est une mycotoxine largement répandue, produite principalement par Aspergillus Ochraceus et Penicillium verrucosum. On la retrouve dans les céréales, mais aussi dans la viande et ses dérivés. Il a été démontré que l'OTA était néphrotoxique, hépatoxique et cancérogène pour tous les mammifères, les porcs et les volailles étant les espèces les plus exposées à sa toxicité. L'objectif de cette étude était d'évaluer les effets de l'OTA introduite dans l'alimentation des porcs sur les performances de croissance et sur la présence de résidus d'OTA dans l'animal. Soixante-quatre porcs, répartis en deux groupes homogènes, ont été élevés pendant 119 jours, de $41 \mathrm{~kg}$ de poids vif jusqu'à l'abattage. Le groupe témoin a été nourri avec un aliment commercial et le groupe expérimental a reçu le même aliment additionné de $25 \mu \mathrm{g} \cdot \mathrm{kg}^{-1}$ d'OTA. Si aucun paramètre de croissance n'a été affecté par le traitement jusqu'à 62 jours de mesure ; à la fin de l'expérience, le poids vif final $(170,9 \mathrm{~kg}$ vs. $163,4 \mathrm{~kg}, P<0,05)$, le gain moyen de poids quotidien $(1094$ vs. $1030 \mathrm{~g}, P<0,01)$ et l'efficacité alimentaire $(-7 \%, P<0,05)$, des porcs consommant l'OTA, ont été diminués ; tandis que l'ingestion alimentaire est restée inchangée. La teneur la plus élevée en OTA a été trouvée dans les reins. Dans le foie et dans le muscle semimembranosus, elle a été largement supérieure à la limite maximale de $1 \mu \mathrm{g} \cdot \mathrm{kg}^{-1}$ fixée par l'Union Européenne pour les denrées destinées à l'alimentation humaine.

ochratoxin A / porcs / performances de croissance / viande

* Corresponding author: luca.malagutti@unimi.it 


\section{INTRODUCTION}

The contamination of animal feed and the potential contamination of animal meat by mycotoxins could present a serious hazard to humans and animals. Ochratoxin A (OTA) is one of the most common and dangerous mycotoxins. OTA is a naturally occurring mycotoxin produced by Aspergillus ochraceus, mainly in tropical regions, and Penicillium verrucosum mainly in temperate areas [18].

Interest in OTA increased in 1994, when the International Agency for Research on Cancer classified OTA as a possible human carcinogen, based on sufficient evidence of carcinogenicity in experimental animal studies [7]. OTA has a potent toxicity and its nephrotoxic, hepatotoxic and carcinogenic effects have been demonstrated in all mammalian species [10]. The products naturally contaminated with OTA include cereal grains, green coffee beans, peanuts, sorghum, olives, poultry and pig meats, cheese, dried fruit, wine and grape juice [8].

The main effects of OTA are related to the reduction of protein, DNA and RNA synthesis due to the properties of OTA which is a powerful competitive inhibitor of phenylalanine-tRNA ligase [20]. Interest in OTA in animal production is limited to monogastric species because the activity of symbiotic microorganisms in ruminants can hydrolyse the peptide bond of OTA into phenylalanine and ochratoxin $\alpha$ which is generally considered to be non-toxic [10]. The target organs of toxicity in monogastric species are mainly the kidneys, but also the liver, which has a detoxification function [4]. In Italy, heavy pigs are reared for more than 9 months and slaughtered at $160 \mathrm{~kg}$ live weight to produce dry-cured products like Parma and San Daniele hams. There is, then, a real risk of using OTA contaminated feed during the long rearing period. OTA can also reduce feed efficiency with subsequent lower growth; it also weakens the immune system.
The aim of this work was to evaluate the effects of OTA in the growing pigs' diet on growth parameters and to calculate the amount of OTA in the animal body and urine.

\section{MATERIALS AND METHODS}

\subsection{Animals and controls}

Sixty-four Large White $\times$ Landrance pigs, $50 \%$ castrated males and $50 \%$ females, from 8 litters, at mean live weight of $41 \mathrm{~kg}$, were divided into 2 homogenous groups of 32 animals each and housed in pens holding 4 animals. The animals used in this study were reared and treated in compliance with the Directive 86/609/EEC relating to the protection of animals used for experimental or other scientific purposes, according to the Italian Legislation with Legislative Decree January 27, 1992 No. 116. The growth period was divided into two phases, which corresponded to different nutrient supplies: the first phase was from the beginning of the trial to the 62 nd day (about $100 \mathrm{~kg} \mathrm{BW}$ ) and the second phase from the 62nd day to the end of the trial (119th day, about $170 \mathrm{~kg} \mathrm{BW}$ ). The control group was given a commercial pig feed for growing pigs (Control diet). The main ingredients of commercial feed were cereals and soybean. According to the Consortium of Parma Ham regulation, cereals in the growing pig diet must be at least $55 \%$ of total dry matter and soybean must not exceed $15 \%$; wheat bran, molasses, animal fat and minerals were the other ingredients. The chemical composition of the feed during the first phase was the following: crude protein $15.9 \%$, crude fibre $4.1 \%$, ether extract $4.6 \%$, ash $5.6 \%$, Net Energy content $2300 \mathrm{kcal} \cdot \mathrm{kg}^{-1}$. In the second phase, the chemical composition was the following: crude protein $17.6 \%$, crude fibre $3.8 \%$, ether extract $5.4 \%$, ash $6.2 \%$, Net Energy content $2360 \mathrm{kcal} \cdot \mathrm{kg}^{-1}$. The natural contamination of feed by OTA was approximately $0.3 \mu \mathrm{g} \cdot \mathrm{kg}^{-1}$. 
For the treated group, the same feed was used with the addition of $25 \mu \mathrm{g} \cdot \mathrm{kg}^{-1}$ of Ochratoxin A from Aspergillus ochraceus (OTA $25 \mu \mathrm{g} \cdot \mathrm{kg}^{-1}$ diet), which was obtained from Sigma-Aldrich s.r.l. Milano. A total of $25 \mathrm{mg}$ of OTA, in a powder state, was dissolved in a methanol-water solution, then it was progressively added to $25 \mathrm{~kg}$ of feed and mechanically stirred; this feed amount was introduced in an industrial ribbon mixer and was blended for 3 hours.

The diets were fed ad libitum and the animals had free access to drinking water.

All pigs were individually weighed at the start of the trial, after 62 and 119 days, just before slaughtering. Live body weight (BW) and average daily weight gain (ADG) were recorded. Feed Intake (FI) of each pen was recorded during the trial to calculate Feed Efficiency (FE). At slaughter, the kidneys, liver and $50 \mathrm{~g}$ of semimembranosus muscle of 4 pigs from each group were collected and immediately stored at $-20{ }^{\circ} \mathrm{C}$.

The meat from 4 pigs of each group was taken to make seasoned sausages; analyses were carried out to determine OTA in fresh sausages, after 40 and 100 days of seasoning. One sample of urine from each group was collected at the beginning of the trial, after $15,45,75,105$ and 119 days and immediately stored at $-20^{\circ} \mathrm{C}$. A sample of urine was manually collected from 4 females, for each group, housed in the same pen.

Ochratoxin A in the kidneys, liver and meat was detected by using an immunoaffinity step followed by HPLC with fluorimetric detection according to Jorgensen and Petersen [9]. Analyses for OTA in urine were carried out using the method described by Pascale and Visconti [15].

\subsection{Statistical analysis}

All data were analysed by ANOVA according to the General Linear Model of the S.A.S. package [16] in order to evaluate the effects of the diet. BW and ADG recorded during the study were covariated with the initial BW. The statistical model employed for BW and ADG was the following:

$$
\mathrm{Y}_{\mathrm{ijk}}=\mu+\alpha_{\mathrm{i}}+\beta_{\mathrm{j}}\left(\mathrm{x}_{\mathrm{ij}}-\mathrm{x}\right)+\gamma_{\mathrm{k}}+\varepsilon_{\mathrm{ijk}}
$$

where $\mu$ was the general average, $\alpha$ the effect of the diet, $\beta$ the correction factor for the covariate, $x$ the average of the observations, $\gamma$ the effect of the pen and $\varepsilon$ the error.

A statistical model without the effect of the pen and without a covariate was employed for FE, FI and OTA contents in semimembranosus muscle, liver and kidneys.

For OTA content in sausage meat, the following model was used:

$$
Y_{i j k}=\mu+\alpha_{i}+\beta_{j}+(\alpha \times \beta)_{i j}+\varepsilon_{i j k}
$$

where $\mu$ was the general average, $\alpha$ the effect of the diet, $\beta$ the effect of seasoning, $(\alpha \times \beta)$ the interaction between the main effects and $\varepsilon$ the error.

Since only one value of urine for each diet was available, no statistical analysis was possible for OTA content in urine.

\section{RESULTS AND DISCUSSION}

Growth parameters of pigs are reported in Table I. All animals were apparently in good health before and throughout the trial. Firm faeces were observed throughout the study with no occurrence of diarrhoea. No significant differences between the groups were observed that were attributable to the pen effect. Initial BW, BW after 62 days, and ADG in the first period of the trial did not differ between the two groups. FI was not significantly affected during the experimental period; the pigs fed the control diet showed heavier final weight: $170.9 \mathrm{~kg}$ vs. $163.4 \mathrm{~kg}(P<0.01)$ after 119 days, and better ADG: $1094 \mathrm{~g}$ vs. $1030 \mathrm{~g}$. As a result of the lower ADG of the treated group, FE at the end of the trial was higher for the control 
Table I. Effects of OTA in feed on growing parameters of pigs.

\begin{tabular}{|c|c|c|c|c|}
\hline & Control & OTA & SE & Significance \\
\hline \multicolumn{5}{|l|}{ Body weights (kg) } \\
\hline Initial $^{1}$ & 40.7 & 41.2 & 0.9 & NS \\
\hline At $62 \mathrm{~d}^{1}$ & 102.1 & 103.7 & 2.0 & NS \\
\hline At $119 \mathrm{~d}^{1}$ & 170.9 & 163.4 & 2.6 & $*$ \\
\hline \multicolumn{5}{|l|}{ Period 1 ( 0 to 62 days $)$} \\
\hline $\operatorname{ADG}^{1}\left(g \cdot d^{-1}\right)$ & 990 & 1015 & 32 & NS \\
\hline Feed Intake ${ }^{2}\left(\mathrm{~kg} \cdot \mathrm{d}^{-1}\right)$ & 3.365 & 3.313 & 0.090 & NS \\
\hline Feed Efficiency ${ }^{2}$ (kg gain per kg feed) & 0.294 & 0.306 & 0.020 & NS \\
\hline \multicolumn{5}{|l|}{ Period 2 (62 to 119 days) } \\
\hline $\mathrm{ADG}^{1}\left(\mathrm{~g} \cdot \mathrm{d}^{-1}\right)$ & 1207 & 1048 & 37 & $* *$ \\
\hline Feed Intake ${ }^{2}\left(\mathrm{~kg} \cdot \mathrm{d}^{-1}\right)$ & 4.418 & 4.428 & 0.125 & NS \\
\hline Feed Efficiency ${ }^{2}$ (kg gain per kg feed) & 0.273 & 0.233 & 0.017 & $*$ \\
\hline \multicolumn{5}{|l|}{ Total trial (0 to 119 days) } \\
\hline $\mathrm{ADG}^{1}\left(\mathrm{~g} \cdot \mathrm{d}^{-1}\right)$ & 1094 & 1030 & 22 & $* *$ \\
\hline Feed Intake ${ }^{2}\left(\mathrm{~kg} \cdot \mathrm{d}^{-1}\right)$ & 3.869 & 3.881 & 0.115 & NS \\
\hline Feed Efficiency ${ }^{2}$ (kg gain per kg feed) & 0.283 & 0.265 & 0.016 & $*$ \\
\hline
\end{tabular}

NS: $P>0.05, *: P<0.05$, **: $P<0.01, * * *: P<0.001$.

1 Data computed from each animal ( $\mathrm{n}=32$ per treatment).

${ }^{2}$ Data computed from each pen ( $n=8$ per treatment).

group (0.283 vs. $0.265 \mathrm{~kg}$ gain per $\mathrm{kg}$ feed, $P<0.05)$

The FE values observed were consistent with data obtained by many authors on heavy pigs fed ad libitum [1, 14]. The decrease of ADG and FE confirms the conclusions of Harvey et al. [6] and Madsen et al. [12] who suggested that OTA can affect growth performance and serum biochemical and haematological values. During the first period (from $40 \mathrm{~kg}$ to $100 \mathrm{~kg}$ ), no significant differences were observed regarding ADG and FE. Only in the second period of the trial did the OTA effect become evident, significantly reducing ADG (1207 g vs. $1048 \mathrm{~g}$ ); it can be concluded, therefore, that two months of ingestion of contaminated feed, at the tested dose, is not long enough to reduce the growth parameters and a reduction occurs only towards the end of the experimental period.

Feed intake did not decrease in the second phase (62-119 days, from $100 \mathrm{~kg}$ to
$170 \mathrm{~kg}$ ), whereas FE was considerably reduced $(0.233$ vs. $0.273, P<0.05)$. This loss of $\mathrm{FE}$ is probably connected to an alteration of protein synthesis caused by OTA, as demonstrated by many authors [2, 20], which determines a reduction in growth.

Table II shows OTA in the kidneys, liver and meat. Due to natural contamination of commercial feed used in the trial, OTA has also been found in the control group. The effect of OTA in the kidneys and liver after 4 months of contaminated ingestion is manifest; at slaughtering, OTA content in the treated group was much higher in the kidneys (69 vs. $\left.10.5 \mu \mathrm{g} \cdot \mathrm{kg}^{-1}, P<0.001\right)$, liver $\left(52\right.$ vs. $\left.3.5 \mu \mathrm{g} \cdot \mathrm{kg}^{-1}, P<0.001\right)$ and in semimembranosus muscle (6.1 vs. $0.88 \mu \mathrm{g} \cdot \mathrm{kg}^{-1}$, $P<0.001)$.

OTA content in the control diet was much lower than $5 \mu \mathrm{g} \cdot \mathrm{kg}^{-1}$, being the maximum limit of tolerance in cereals fixed by the EEC regulation 472/2002 [3] for human feed, however it was enough to determine, 
Table II. Effect of feed OTA on Ochratoxin A in meat.

$\left.\begin{array}{lcccc}\hline & \text { Control } & \text { OTA } & \text { SE } & \text { Significance } \\ \hline \text { Semimembranosus muscle }\left(\mu \mathrm{g} \cdot \mathrm{kg}^{-1}\right) & 0.88 & 6.10 & 0.20 & * * * \\ \text { Kidneys }\left(\mu \mathrm{g} \cdot \mathrm{kg}^{-1}\right) & 10.50 & 69.00 & 0.54 & * * * \\ \text { Liver }\left(\mu \mathrm{g} \cdot \mathrm{kg}^{-1}\right) & 3.50 & 52.00 & 0.74 & * * * \\ \text { Sausage meat } 0 \text { days }\left(\mu \mathrm{g} \cdot \mathrm{kg}^{-1}\right) & 0.70 \mathrm{a} & 5.00 \mathrm{~b} \\ \text { Sausage meat } 40 \text { days }\left(\mu \mathrm{g} \cdot \mathrm{kg}^{-1}\right) & 0.90 \mathrm{a} & 4.65 \mathrm{~b} \\ \text { Sausage meat } 100 \text { days }\left(\mu \mathrm{g} \cdot \mathrm{kg}^{-1}\right) & 0.95 \mathrm{a} & 5.25 \mathrm{~b}\end{array}\right\} \quad \begin{aligned} & \\ & \text { NS: }\end{aligned}$

NS: $P>0.05, *: P<0.05, * *: P<0.01, * * *: P<0.001$.

Means followed by different letters differ significantly at $P<0.05$.

after lengthy exposure, a final detectable amount in the kidneys, liver and muscle. On examination, the kidneys and liver of the treated group presented visible lesions, soft consistency and a serious haemorrhagic condition.

Recorded data confirm the conclusions of many authors who suggest that the kidneys and liver are the target organs for OTA and, according to van Egmond and Speijers [19], the highest content was found in the kidneys. OTA content in the semimembranosus muscle was lower than in the kidneys and liver, as suggested by Gareis [4] and by Jorgensen [8]. Madsen et al. [13] also found a higher level of OTA in the kidneys than in meat, however, this difference was lower than that found by the other authors.

OTA content was lower in sausage meat than in semimembranosus muscle, as shown in Table II. The values observed for the treated group were consistent with the results of previous studies $[5,11]$. Lard is added to fresh meat to produce sausages and, according to Gareis [4], OTA accumulates more in muscle than in adipose tissue; as a consequence, OTA content in sausages is lower.

Statistically significant differences, regarding OTA content in sausages, were observed between groups, whereas no differences were found between the different times of seasoning $\left(0.70 \mu \mathrm{g} \cdot \mathrm{kg}^{-1}, 0.90 \mu \mathrm{g} \cdot \mathrm{kg}^{-1}\right.$, $0.95 \mu \mathrm{g} \cdot \mathrm{kg}^{-1}$ and $5.00 \mu \mathrm{g} \cdot \mathrm{kg}^{-1}, 4.65 \mu \mathrm{g} \cdot \mathrm{kg}^{-1}$, $5.25 \mu \mathrm{g} \cdot \mathrm{kg}^{-1}$ for the control and treated group respectively after 0,40 and 100 days of seasoning). These data confirm the conclusions of many authors $[11,17]$ who suggested that production procedures such as seasoning and storage have no effects on the reduction of OTA levels in meat products.

OTA content in urine was determined at the beginning of the trial, after 15, 45, 75, 105 and 119 days. In the control group, OTA was never found, during the whole experimental period; in the treated group, OTA was absent at the beginning of the trial and it was detected at 3.10, 3.50, 3.60, 4.35 and $3.70 \mu \mathrm{g} \cdot \mathrm{kg}^{-1}$. According to Pascale and Visconti [15], there is a clear correlation between OTA intake and OTA concentration in urine, so the determination of OTA in urine could be used as a rapid and noninvasive tool to verify OTA contamination in piggeries, therefore avoiding the need to analyse all feeds used throughout the growing period.

\section{CONCLUSIONS}

The results of this experiment indicate that the addition of $25 \mu \mathrm{g} \cdot \mathrm{kg}^{-1}$ of Ochratoxin $\mathrm{A}$ to the diet of growing swine can determine decreased growth rate and feed efficiency whilst feed intake is not affected. The decrease of growth rate becomes evident from the third month of intake of contaminated feed. The final amount of ochratoxin A was very high in the kidneys and 
liver and, it probably reduced the functionality of these organs causing lower growth. The final OTA content in meat was much higher than the maximum limit of $1 \mu \mathrm{g} \cdot \mathrm{kg}^{-1}$ established by the European Union for human consumption food; seasoning and storage do not seem to have any effect on the reduction of the levels of ochratoxin A in meat products. OTA content in urine could be used as a rapid and non-invasive tool in monitoring OTA contamination in piggeries.

\section{ACKNOWLEDGEMENTS}

This work was carried out with the financial support of Regione Lombardia-Piano di Sviluppo Agricolo 2001-2003.

This paper must be attributed equally to the authors.

\section{REFERENCES}

[1] Camp L.K., Southern L.L., Bidner T.D., Effect of carbohydrate source on growth performance, carcass traits, and meat quality of growing-finishing pigs, J. Anim. Sci. 81 (2003) 2488-2495.

[2] Dirheimer G., Mechanistic approaches to ochratoxin toxicity, Food Addit. Contam. 13 (Suppl.) (1996) 45-48.

[3] European Community, EC regulation No. 472/2002 of March 12, 2002, The Official Journal of the European Communities L75/ 18, March 16, 2002

[4] Gareis M., Fate of ochratoxin A on processing of meat products, Food Addit. Contam. 13 (Suppl.) (1996) 35-37

[5] Gareis M., Scheuer R., Ochratoxin A in meat and meat products, Arch. Lebensmittelhyg. 4/5 (2000) 102-104

[6] Harvey R.B., Kubena L.F., Elissalde M.H., Rottinghaus G.E., Corrier D.E., Administration of ochratoxin $\mathrm{A}$ and T-2 toxin to growing swine, Am. J. Vet. Res. 12 (1994) 1757-1761.

[7] International Agency for Research on Cancer, Ochratoxin A, IARC, Monographs on the Evaluation of Carcinogenic Risks to Humans, IARC, Lyon, France, Vol. 56, 1994, pp. 489521.
[8] Jorgensen K., Survey of pork, poultry, coffee, beer and pulses for Ochratoxin A, Food Addit. Contam. 15 (1998) 550-554.

[9] Jorgensen K., Petersen A., Content of ochratoxin $\mathrm{A}$ in paired kidney and meat samples from healthy Dasnish slaughter pigs, Food Addit. Contam. 6 (2002) 562-567.

[10] Karlovsky P., Biological detoxification of fungal toxins and its use in plant breeding, feed and food protection, Nat. Toxins 7 (1999) $1-23$.

[11] Lusky K., Tesch D., Göbel R., Doberschütz K.D., Ochratoxin A residues in pigs and in food prepared from pig meat, Fleischwitschaft 5 (1994) 558-560.

[12] Madsen A., Hald B., Lillehoj E., Mortensen H.P., Feeding experiments with ochratoxin A contaminated barley for bacon pigs. 2. Naturally contaminated barley given for 6 weeks from $20 \mathrm{~kg}$ compared with normal barley supplemented with crystalline ochratoxin A and/ or citrinin, Acta Agr. Scand. 32 (1982) 369372.

[13] Madsen A., Mortensen H.P., Hald B., Feeding experiments with ochratoxin A contaminated barley for bacon pigs. 1. Influence on pig performance and residues, Acta Agr. Scand. 32 (1982) 225-239.

[14] Martelli G., Parisini P., Scipioni R., Cessi E., Sardi L., The effects of pressed sugar beet pulp silage (PBPS) and dairy whey on heavy pig production, Ital. J. Anim. Sci. 1 (2002) 25-33.

[15] Pascale M., Visconti A., Rapid method for the determination of ochratoxin $\mathrm{A}$ in urine by immunoaffinity column clean-up and highperformance liquid chromatography, Mycopathologia 152 (2000) 91-95.

[16] Statistical Analysis System Institute, SAS/ STAT User's Guide: statistics, release, 8th ed., Sas Institute Inc., Cary, 2000.

[17] Scheuer R., Untersuchungen zum vorkommen von Ochratoxin A, Fleischwirtschaft 69 (1989) 1400-1404

[18] Teren J., Varga J., Hamari Z., Rinyu E., Kevei E., Immunochemical detection of ochratoxin A in black Aspergillus strains, Mycopathologia 134 (1996) 171-176.

[19] van Egmond H.P., Speijers G.J.A., Survey of data on the incidence and levels of ochratoxin $\mathrm{A}$ in food and animal feed worldwide, J. Nat. Toxins 2 (1994) 125-144.

[20] Xiao H., Madhyastha S., Marquardt R., Li S., Vodela J.K., Frohlich A.A., Kemppainen B.W., Toxicity of ochratoxin A, its opened lactone form and several of its analogs: structure-activity relationships, Toxicol. Appl. Pharm. 137 (1996) 182-192. 